\title{
Plantago major in Traditional Persian Medicine and modern phytotherapy: a narrative review
}

Younes Najafian ${ }^{1}$, Shokouh Sadat Hamedi ${ }^{2}$, Masoumeh Kaboli Farshchi ${ }^{3}$, Zohre Feyzabadi ${ }^{4}$

${ }^{1}$ Ph.D. Student, Students Research Committee, Department of Persian Medicine, School of Persian and Complementary Medicine, Mashhad University of Medical Sciences, Mashhad, Iran

${ }^{2}$ Ph.D. of Persian Pharmacy, Department of Persian Pharmacy, School of Persian and Complementary Medicine, Mashhad University of Medical Sciences, Mashhad, Iran

${ }^{3}$ Ph.D. Student, Department of Persian Medicine, School of Persian and Complementary Medicine, Mashhad University of Medical Sciences, Mashhad, Iran

${ }^{4}$ Assistant Professor of Persian Medicine, Department of Persian Medicine, School of Persian and Complementary Medicine, Mashhad University of Medical Sciences, Mashhad, Iran

\section{Type of article: Review}

\begin{abstract}
Plantago major has been used widely since ancient times, to manage a wide range of diseases including constipation, coughs and wounds. The aim of this study is to review the traditional application, botanical characterization, pharmacological activities, phytochemistry effects and toxicity of Plantago major. In this review study, medicinal properties of Plantago major are collected from credible pharmacopeias, textbooks of traditional Persian medicine (TPM) belonging to the 10-18th century AD, such as "The Canon of Medicine", "Makhzan-AlAdvia" and so on. Moreover, electronic databases including Scopus, Medline and Web of science were explored for this purpose. Plantago major has been prescribed in various forms such as roasted seeds, decoction, syrup, liniment, gargle, rectal enema, vaginal suppository, eye and nasal drop for each illness by TPM scholars. Some of its traditional properties including wound healing, antipyretic, antitussive, anti-infective, anti-hemorrhagic, antiinflammatory, diuretic, laxative, astringent and hemostatic have been confirmed in recent researches. Phytochemical investigations showed that Plantago major contains volatile compounds, triterpenoids, phenolic acids and flavonoids. Modern pharmacological studies have proven some of the traditional applications of Plantago major. Nevertheless, more investigations are required on this plant, because it has the potential to be used to produce various natural medications.
\end{abstract}

Keywords: Plantago major, Great plantain, Phytotherapy, Pharmacology, Traditional Persian Medicine

\section{Introduction}

Plantago major (P. major), commonly known as great plantain, is a widespread used medicinal plant from the Plantaginaceae family (1). Plantago major is called "Lesan-ol-haml" or "Barhang" in Traditional Persian Medicine (TPM) (2). Researchers believed that Plantago major has existed for nearly 4000 years, especially in Europe, America and Asia. In addition, Plantago major grows wildly and has been used since ancient times in most parts of Iran (3). TPM scholars believed that the entire world is made up of four elements (air, water, fire, soil). Thus, everything has an exclusive quality based on dominant element(s) in its structure and this exclusive quality named temperament (Midzaj) (2). Temperament reality existed in traditional medicines such as TPM, Greek, European, Arabic, Indian, and Chinese (4). According to TPM, Plantago major has cold and dry temperament and has been used to decline inflammation and bleeding (2). Plantago major contains several active compounds such as flavonoids, polysaccharides, terpenoids, lipids, iridoid glycosides and caffeic acid derivatives (5), and is used in treatment of various diseases such as constipation, coughs, wounds, infection, fever, bleeding and inflammation (3).

\section{Corresponding author:}

Assistant Professor Dr. Zohre Feyzabadi. Department of Persian Medicine, School of Persian and Complementary Medicine, Mashhad University of Medical Sciences, Mashhad, Iran.

Tel: +98.5138848930, Fax: +98.5138829279, Email: Feyzabadiz@mums.ac.ir

Received: August 05, 2017, Accepted: September 28, 2017, Published: February 2018

iThenticate screening: September 28, 2017, English editing: February 12, 2018, Quality control: February 15, 2018

This article has been reviewed / commented by four experts

(C) 2018 The Authors. This is an open access article under the terms of the Creative Commons Attribution-NonCommercialNoDerivs License, which permits use and distribution in any medium, provided the original work is properly cited, the use is non-commercial and no modifications or adaptations are made. 
In this review, pharmacological properties, adverse events, toxicity, and applications of Plantago major are evaluated based on both Modern and Traditional Phytotherapy, and beneficial approaches might be provided for future clinical trials, and new pharmaceutical compounds of plantain are made.

\section{Material and Methods}

In this review, initially, TPM books were investigated for the applications of Plantago major in therapeutic purposes. The most important pharmacopeias, pharmaceutical and medical books between the $10^{\text {th }}$ and $18^{\text {th }}$ century $\mathrm{AD}$, including "The Canon of Medicine" (Avicenna, 980-1037), "Zakhire Kharazmshahi” (Jorjani, 1042-1136) and "Makhzan-Al- Advia" (Aghili, 19 th $^{\text {th }}$ century) were considered in TPM books, for this purpose. These works of literature are a part of the training skills of students at the Faculty of Traditional and Complementary Medicine and Traditional Pharmacy in Iran. Then, scientific databases including Medline, Scopus and Web of science were assessed regarding "Plantago major" and "plantain" keywords for pharmacological effects of this plant by searching the Persian and English articles (From 1960-2016). Finally, the reported therapeutic and pharmacological properties of Plantago major were investigated to confirm its aforementioned effectiveness in TPM.

\section{Results}

\subsection{Plantago major from the perspective of TPM}

\subsubsection{Temperament of Plantago major in TPM}

TPM physicians believed that the temperament of Plantago major is cold and dry. Basically the cold temperament is because of both water and soil elements, and soil component leads to its dry and astringent temperament. According to traditional medicine experts, temperament means the dominant quality of the composite object, and it is made of the interaction of four basic qualities (hot, cold, wet, and dry). From this viewpoint, both individuals and plants have a certain temperament. Temperament has an important function in maintaining the ideal healthy state of an individual. To determine the temperament in plants, you must check the plant's effect after entering the human body. After the consumption of the plants, if the body of the human is warmer, colder, dryer, or wetter than before, the temperament of the plant is warm, cold, dry or wet, respectively. After usage of $P$. major, the body's temperament had a cold and dry quality. Dryness and astringency in the seed and root is more than in the leaf $(2,6)$. As a result, seed of Plantago major is more useful for stopping bleeding, especially if it is roasted $(2,6,7)$. In traditional medicine, mucilage is one of the important parts of this plant and in addition to drug use, it is used as a binder in the production of some dosage forms such as "habb" or tablets (8).

\subsubsection{The history of Plantago major}

The use of plantain to treat various diseases goes back thousands of years. The earliest known account of the Plantain is in the "Materia Medica" or "Hashayesh" in Arabic, which was written by "Pedanius Dioscorides" (40-90 AD), a Greek botanist. His book is an encyclopedia on herbal medicine and pharmacopeia from around the world (9, 10). There is an image of Dioscorides and Plantago major in Materia Medica that was painted by Dioscorides. After the advent of Islam, experts and distinguished scientists like Rhazes, Avicenna and al-Biruni appeared in the Islamic medical schools. They introduced herbs and discussed the properties of each herb such as P. major, including: its temperament, habitat, indications, contraindication, duration of action, effectiveness, toxicity, dosage, types of preparations, and side effects $(7,11,12)$.

\subsubsection{Mode of application in TPM}

\subsubsection{Neurological uses}

This plant has been used to cure epilepsy lonely, either exclusively, or with other herbs such as cooked lentils with plantain leaves, which in traditional Persian medicine, is called "Adasiyyat". It also helps to improve nervous pains such as earache by using drops or massage of mucilage, or nasal inhalation $(2,7)$.

\subsubsection{Ophthalmic effects}

Plantago major is effective in the treatment of many eye diseases including eye choroid diseases, day blindness, conjunctivitis and eyes sores. Leaf juice has been used as drops with other herbs or independently, in addition to the oral form. $(2,12,13)$.

3.1.3.3. ENT effects

Plantago major is advised for toothache, earache, halitosis, oral lesions, mouth sores, epistaxis, hemoptysis, loose teeth, gingivitis and tonsillitis by gargling the juice of the leaves or its decoction, or dropping in the ear and applying semi hot dry leaves on the location $(2,12,13)$.

\subsubsection{Pulmonary effects}

Plantago major can treat hemoptysis, asthma, tuberculosis, lung and plural lesions and it was used as decoction and incense. The leaf extract was suitable for treating lung and plural lesions. Taken orally with honey is the most desirable dosage form for treating pulmonary disorders $(2,12,13)$. 


\subsubsection{Gastrointestinal effects}

Plantago major is effective in upper and lower gastrointestinal bleeding, hematemesis, dysentery, hemorrhoids, stomachache, intestinal ulcers, dyspepsia and constipation by eating the extract and baking leaves with salt and vinegar or enema of extract or its mucilage $(2,3,12,13)$.

3.1.3.6. Hepatic, splenic effects

Plantago major extract and seed or root has been extensively applied as liver tonic and advised in obstructive diseases of liver and spleen $(2,12,13)$.

3.1.3.7. Urogenital effects

Plantago major is prescribed in uterus wart, uterus ulcer, menometrorrhagia and polymenorrhea in the form of oral or vaginal $(2,14)$. Due to diuretic effect of Plantago major, it is also advised for urinary retention, hematuria, and bladder and kidney pain. For this aim, it was used as plaster or oil on the skin, locally $(2,12,13)$.

3.1.3.8. Dermatologic effects

Plantago major is used in different kinds of wound and skin diseases in TPM such as deep wound, purulent wound, chronic and progressive wound, malignant wound, fire burn, erysipelas, progressive blister, pruritus, irritating urticarial and fistula, by sprinkling the plant powder on the wound or its plaster with salt or separately. It is also used for head and face skin ulcers in the same manner $(2,7,12,13,15)$.

\subsection{Plantago major from the perspective of modern medicine}

\subsubsection{Plantaginaceae family}

Plantago major (P. major) belongs to the Plantaginaceae family. It grows as a native plant in Asia, Europe, and America and nearly all parts of Iran. To date, 275 Plantago species have been identified worldwide (1). The Plantaginaceae family is variant in Iran, and includes Plantago amplexicaulis, Plantago ciliata, Plantago Coronopus, Plantago indica, Plantago lanceolata, Plantago major, Plantago ovata Forssk and Plantago Psyllium (3).

\subsubsection{Morphology}

Plantago major is a glabrous or little pubescent, perennial with one rosette. The leaves are broad ovate, with a length and width of 5 to $15 \mathrm{~cm}$ and 4 to $8 \mathrm{~cm}$ respectively, it also has short roots and 3-9 prominent veins. Stem length is 10-70 cm standing, and has no groove. The plant also has plenty of small flowers growing between May to September and is subtended by 1-2 mm bracts, ovate, glabrous, brownish white with green keel. Sepals are green with the length of 1.5-2.5 mm. The seeds are two celled, small, dark and ovoid with fruit length 2-4 $\mathrm{mm}(3)$.

\subsubsection{Phytochemistry of Plantago major}

Phytochemical studies of Plantago Spp, have determined the presence of various metabolites to date; furthermore, about 60 secondary metabolites have been identified from the Plantago herb including phenylethanoid glycosides, triterpenoids, polysaccharides, phenolic acids and other compounds $(1,16-19)$ such as alkaloids, caffeic acid derivatives, coumarins, fats and oils, mucilage, polysaccharides, sterols and volatile substances (20-22). According to a number of studies of various leaf extracts, (petroleum ether, methanol, ethyl acetate, n-butanol and aqueous) 51 components were isolated. Most components in petroleum ether extract were phytol, benzofuranone, pentanediol and benzene propanoic acid and in methanol extract, group of diglycerol and glycol contain organic acids, such as fumaric acid, syringic acid, vanillic acid, p-hydroxy benzoic acid, ferulic acid, p-coumaric acid, gentisic acid, traces of salicylic acid, benzoic acid and cinnamic acid were found. In ethyl acetate extract, glycerine, benzene and dibutyl phthalate were isolated and in n-butanol extract, there were phthalic acid, benzene propanoic acid and groups of phenols. Finally, in aqueous extract ethnophenol, diathiapentene, napthalenone and glycerine were found. Additionally, all of these five extracts had phenol groups (23).

\subsubsection{Pharmacological effects}

\subsubsection{Immune Enhancing Effects}

Methanol extracts of P. major leaves, increase creation of nitric oxide (NO), tumor necrosis factor-alpha (TNF- $\alpha$ ) and stimulate lymphocyte proliferation, so activated macrophages are produced in a variety of cytotoxicity such as nitric oxide, TNF- $\alpha$ and lymphokines. As a result, it can prevent the development of tumors and infections (24). Plantago major shows immunomodulatory activity, increasing lymphocyte proliferation and secretion of interferon$\gamma$ at low concentrations $(<50 \mu \mathrm{g} / \mathrm{ml})$, but at high concentrations, it can inhibit this property $(<50 \mu \mathrm{g} / \mathrm{ml})$. The hot water extracts of Plantago major can help to improve leukemia, carcinoma and viral infections (25).

\subsubsection{Hepatoprotective Effects}

In recent years, hepatic disorders have been the main cause of deaths around the world (26). In one model of animal study, extract of Plantago major seed, exhibits the hepatoprotective activity by which the levels of alanine aminotransferase (ALT) and aspartate aminotransferase (AST) showed reduction $(26,27)$. 


\subsubsection{Gastrointestinal effects}

Due to the anti-inflammatory effect of Plantago major, it can be used to treat endoparasites and stomach problems in animals. The polyholozidic fraction separated from the leaves and seeds of some Plantago species (Plantago major, media, lanceolata) explains its gastro protective action, and a laxative effect was obtained with higher doses of Plantago major (28-30). The seeds of the plant have a high gastro protective effect in comparison to the leaves, which may be as a result of high content from mucilage. A water immersion-stress ulcer model was used on rats to test the plant extract's ability to inhibit ulcers. Acidity and gastric fluid were significantly decreased by extract which may be due to inhibition of gastric acid secretion and increase of mucosal defensive factors $(31,32)$. On the other hand, Plantago leaves extract decreased the motility of duodenum and also had antidiarrheal effect in oral administration (33). Plantago major seeds are recommended for inflammatory bowel disease (IBD). Although the oral administration of leaf extract can decrease gastric ulcers, the seed extract has no effect. But both seed and leaf extracts can decrease total acidity as well (31).

3.2.4.4. Pulmonary effects

Plantago major inhibits mast-cell degranulation and can be used for treating asthma and allergic disease (34). It protects against pneumococcal infection in mice and treatment of chronic bronchitis $(35,36)$.

\subsubsection{Urinary effects}

Plantago major has diuretic effects (37) and can also inhibit activity of angiotensin converting enzyme (38). Another study on extract of Plantago major showed that it is more efficient than allopurinol and potassium citrate in inhibiting the size of the calcium oxalate crystal in-vitro and it can be consumed to improve urolithiasis (39).

\subsubsection{Dermatologic effects}

Plantago major is an effective herb in the management of acute urticaria (40). Ursolic acid, oleanolic acid and $\alpha$ linolenic acid are three Plantago major components that have shown inhibitory effects on COX-2 catalyzed prostaglandin production. Luteolin (one of the flavonoids) also has the ability to suppress leukocyte migration and inhibit mast cell degranulation which all together can be considered as anti urticaria treatment strategies (41).

3.2.4.7. Anti-hypercholesteremia, Anti-atherosclerosis and Hypoglycemic effect

Plantago major leaves can inhibit progressions of atherosclerosis and hypercholesteremia in animals via the lecithin/cholesterol ratio (42). Plantago major seeds have hypoglycemic effect in mice (43). Plantagoside and its aglycone in Plantago major seeds inhibit protein cross-linking glycation and have potential beneficial applications in the prevention of diabetic complications (44).

\subsubsection{Antinociceptive Effects}

Methanolic extracts of leaves, seeds or aqueous extract of plant have shown anti-inflammatory and analgesic activities through inhibition of prostaglandins synthesis (45).

3.2.4.9. Antioxidant and Free Radical Scavenging Effects

Ethanolic hot and cold water extracts of Plantago major leaves and seeds have antioxidant activity (46-49). Plantago major contains flavonoids such as luteolin, apigenin, hispidulin and baicalein, which can induce carcinoma cell death. In addition, Plantago extracts have inhibitory and cytotoxic effects on breast adenocarcinoma and melanoma cell lines and these preliminary results could be justified by the cytotoxic activity of the flavone, luteolin7-O- $\beta$-glucoside, the major flavonoid in Plantago species (50).

\subsubsection{Anti-infective, Antibiotic, Antifungal, Antiviral, Antimalarial and Anti-giardiasic Effect}

Some types of Plantago major extract were effective in the treatment of fungal, bacterial and viral infections. Antimalarial and anti-Giardia effects of plant have been proven as well $(5,51-54)$. However, the aqueous extract of Plantago major had a slight anti-herpes virus activity versus the caffeic acid, which exhibited the strongest activity against HSV-1, HSV-2 and ADV-3. However, chlorogenic acid possessed the strongest anti-ADV-11 activity (51). Ethyl alcohol extract showed antibacterial activity against E. coli and Bacillus cereus and acetone extract was effective on bacteria species (Bacillus cereus, Bacillus subtilis, Staphylococcus aureus, Staphylococcus epidermidis, Escherichia coli, Klebsiella pneumonia, Pseudomonas aeruginosa, Proteus mirabilis, Salmonella enteritidis) in different concentrations (52). Plantago major extract also showed acceptable potency against C. albicans (ATCC 66027) comparable to synthetic antifungal agents (54).

3.2.4.11. Anticancer and Cytotoxic Activity

Methanolic Plantago major extract was evaluated for cytotoxic activity against three human cancer cell lines including the human renal adenocarcinoma (TK-10), the human breast adenocarcinoma (MCF-7) and the human melanoma (UACC- 62). Flavonoids, flavone and luteolin are the main factors in cytotoxic activity (55). Plantago major may be partially effective in preventing carcinogenesis (56). The cytotoxic activity of Plantago major methanol extract on human transformed cells: HCT-15 (colon carcinoma), SQC-UISO (cervical carcinoma), OVCAR (ovary carcinoma) and KB (nasopharynx carcinoma) has also been evaluated, in vitro (57). Aqueous and methanol extracts of Plantago major also stimulate cell proliferation in bone marrow and spleen cell cultures. 
Although the same number of cells was cultured in both types of tumor, cell population was significantly higher in spleen cultures than in bone marrow cultures. In fact, oleanolic acid and ursolic acid stimulated the proliferation of splenocytes and enhanced the recovery of hematopoietic system (57).

\subsubsection{Wound Healing Effects}

Plantago major was used in wound healing and the leaves were used as a remedy of wounds. Anti-inflammatory action is via a complex event linked to tissue damage whether by bacteria, physical trauma, chemical, heat or any other phenomenon. Also, inflammatory response is the critical protective reaction to these kinds of injures remarked by redness, fever, edema (swelling) and pain in involved tissue (32). In an animal study, water extract of Plantago major is recommended as a suitable substitute for silver sulfadiazine, especially when applied in $50 \%$ concentration in wound burn healing (58). Polyphenols especially plantamajoside are considered as the main significant compounds for wound healing (59).

3.2.4.13. Adverse reactions

Plantago major is a safe plant, but some adverse reactions such as: nausea, vomiting, diarrhea, anorexia, bloating, hyper-sensitivity and dermatitis may arise after treatment. Life threatening anaphylaxis may occur in more serious cases in over dose usage (60).

\subsubsection{Safety and toxicity}

Daily dosage is 3-5 g of the powdered herb 1-3 times daily but the most common dose as infusion is $150 \mathrm{ml}$ (one cupful) 3-4 times a day (60). The Plantago major may be prepared in either a dried state or as an extract before being packaged and distributed in a form suitable for oral administration, including capsules, pills, coated pills, tablets and dragee (25). Plantago major is not among the most toxic of plants. Analysis of the anti-nutritional and toxic components showed low content of oxalic acid $(6736 \mathrm{mg})$ and erucic $(3.45 \%)$ in Plantago major extract (61). Furthermore, LC50 and LD50 for Plantago major were determined as $4.74(\mu \mathrm{g} / \mathrm{mL})$ and $182.54(\mathrm{mg} / \mathrm{kg})(62)$ and median effective dose (ED50) value of Plantago major was found to be $7.507 \mathrm{mg} / \mathrm{kg}$ (14). Plantago major also has phenol groups (63).

\section{Discussion}

To conclude, lesan-ol-haml or barhang in TPM is equivalent to the great plantain with the scientific name of Plantago major $(1,2)$. In this review study, we found Plantago major was widely prescribed by TPM physicians in various forms from 1000 years ago $(2,7)$. Although recent studies have proved many therapeutic effects of $P$. major some of the old traditional applications of this plant are not examined. For example, we did not find any evidence for clinical applications of P. major in scrofula, kerion, hematemesis and hemoptysis (Table 1).

Table1. Plantago major applications in TPM and Modern Medicine

\begin{tabular}{|c|c|c|c|c|c|}
\hline \multirow[t]{2}{*}{ System } & \multicolumn{3}{|c|}{ Traditional Persian Medicine } & \multirow[t]{2}{*}{ Modern Medicine } & \multirow[t]{2}{*}{ Ref. no. } \\
\hline & Part of plant & Mode of application & Disease & & \\
\hline Neurologic & Leaves & $\begin{array}{l}\text { Foodstuff with lentil, } \\
\text { Plaster on Forehead }\end{array}$ & Epilepsy & Effects GABA system and reduces seizure & $2,7,67$ \\
\hline \multirow[t]{6}{*}{ Urogenital } & Leaves, seed & $\begin{array}{l}\text { Vaginal suppository, } \\
\text { Plaster on the pubis, } \\
\text { Vaginal washing }\end{array}$ & Menorrhagia & $\begin{array}{l}\text { Plant extracts showed }[\mathrm{H}]-17 \beta \text {-estradiol from both } \\
\text { receptor subtypes and had significant activity in the } \\
\text { binding assay Plantago major (PM) enhanced the } \\
\text { expression of all pS2, PR and PTGES mRNAs in the } \\
\text { presence of E2, also indicating an estrogen agonist } \\
\text { effect. }\end{array}$ & 2,66 \\
\hline & Leaves, seed & Vaginal suppository & $\begin{array}{l}\text { Uterine pain caused by } \\
\text { congestion }\end{array}$ & Tonus-raising effect on the uterus & 2,68 \\
\hline & $\begin{array}{l}\text { Leaves, Seed, } \\
\text { Root }\end{array}$ & Oral extract & $\begin{array}{l}\text { Urinary retention, } \\
\text { Kidney's ducts } \\
\text { obstruction }\end{array}$ & $\begin{array}{l}\text { Greater urine flows, with the diuretic effects of } \\
\text { Iridoid compounds }\end{array}$ & $2,7,69$ \\
\hline & $\begin{array}{l}\text { Leaves, seed, } \\
\text { Root }\end{array}$ & Oral extract & Hematuria & $\begin{array}{l}\text { Antiurolithiatic by dissolving the stone by iridoid } \\
\text { glycosides }\end{array}$ & 2,70 \\
\hline & Leaves, seed & $\begin{array}{l}\text { Oral extract, } \\
\text { Liniment }\end{array}$ & Bladder pain & $\begin{array}{l}\text { Analgesic activities by inhibition of prostaglandins } \\
\text { synthesis }\end{array}$ & \begin{tabular}{|l|}
$2,6,7$ \\
45
\end{tabular} \\
\hline & Leaves & Oral extract & Dysuria & Aucubin and catalpol have diuretic effect. & 1,2 \\
\hline Ophthalmic & Leaves & $\begin{array}{l}\text { Eye ointment, } \\
\text { Liniment }\end{array}$ & Conjunctivitis & $\begin{array}{l}\text { Plant has antiviral activity against conjunctivitis } \\
\text { caused by herpes simplex virus (types: HSV-1, HSV- } \\
\text { 2) and adenovirus (types: ADV-3, ADV-8, ADV-11) }\end{array}$ & $\begin{array}{l}2,6,7 \\
51\end{array}$ \\
\hline \multirow[t]{2}{*}{$\mathrm{ENT}^{2}$} & Leaves & Nasal drop & Epistaxis & Not found & 2,6 \\
\hline & Leaves & Ear drop & Otitis & $\begin{array}{l}\text { Analgesic activities by inhibition of prostaglandins } \\
\text { synthesis }\end{array}$ & $\begin{array}{l}2,6,7 \\
45\end{array}$ \\
\hline
\end{tabular}




\begin{tabular}{|c|c|c|c|c|c|}
\hline & Leaves, Root & Gargle & $\begin{array}{l}\text { Aphthous stomatitis } \\
\text { Mouth ulcers, } \\
\text { Gingivitis, toothache }\end{array}$ & $\begin{array}{l}\text { Analgesic and anti-inflammatory activities antifungal } \\
\text { and oral antimicrobial, antinociceptive effects. } \\
\text { (tannin) }\end{array}$ & $\begin{array}{l}2,6,7 \\
71\end{array}$ \\
\hline & Root & Hanging & Scrofula & Not found & 6,7 \\
\hline & Leaves & Gargle & Tonsillitis & Anti-inflammatory by flavonoid and tannin contents & 6,72 \\
\hline \multirow[t]{3}{*}{ Pulmonary } & $\begin{array}{l}\text { Leaves, seed, } \\
\text { Root }\end{array}$ & $\begin{array}{l}\text { Oral syrup, seed's } \\
\text { powder, Plaster of } \\
\text { leaves extract on the } \\
\text { chest }\end{array}$ & Hemoptysis & Not found & $2,6,7$ \\
\hline & Leaves & foodstuff with lentil & Asthma & $\begin{array}{l}\text { Increase number of mast cells, thickness of alveolar } \\
\text { epithelium and accumulation of glycoprotein in } \\
\text { airways. }\end{array}$ & $\begin{array}{l}2,6,7 \\
36\end{array}$ \\
\hline & Leaves & Oral extract, plaster & Tuberculosis & $\begin{array}{l}\text { Effect on Mycobacterium tuberculosis in agar- } \\
\text { dilution MIC } \text { M }^{3} \text { extract: }>1 \mathrm{mg} / \mathrm{ml}\end{array}$ & $2,6,73$ \\
\hline \multirow[t]{5}{*}{ Gastrointestinal } & Leaves & Oral extract & Hematemesis & Not found & 2 \\
\hline & Leaves & Oral extract & Hemorrhoid & Effect on anorectal diseases by $10 \%$ plantain cream. & $2,7,74$ \\
\hline & Leaves, seed, & $\begin{array}{l}\text { Oral extract, rectal } \\
\text { enema }\end{array}$ & $\begin{array}{l}\text { Ulcerative colitis, } \\
\text { Dysentery }\end{array}$ & $\begin{array}{l}\text { Gastroprotective effect by polyholozide obtained } \\
\text { from seeds and leaves. } \\
\text { Decreasing the average ulcer index. Antidiarrheal } \\
\text { effect. Transient stimulation of motility on rabbit's } \\
\text { isolated duodenum. }\end{array}$ & $\begin{array}{l}2,7,29, \\
75\end{array}$ \\
\hline & Leaves & Oral extract & $\begin{array}{l}\text { Tonic in liver and } \\
\text { spleen, Obstruction in } \\
\text { liver ducts }\end{array}$ & $\begin{array}{l}\text { Hepatoprotective activities. on spleen as a } \\
\text { hematopoietic }\end{array}$ & 2,26 \\
\hline & Leaves & foodstuff with lentil & Ascites & Inhibitory effect against Ehrlich ascites carcinoma. & $6,7,76$ \\
\hline \multirow[t]{6}{*}{ Dermatologic } & Leaves, seed & Plaster & Kerion & Not found & 6 \\
\hline & Leaves & Plaster & Deep wound & $\begin{array}{l}\text { The findings for } P \text {. major showed neoepithelium and } \\
\text { skin appendages formation. The alkaloids in the herb } \\
\text { are responsible for improvement of healing incisions } \\
\text { by increasing the tensile strength of the scar tissue. }\end{array}$ & $\begin{array}{l}2,6,77 \\
78\end{array}$ \\
\hline & Leaves & Plaster & Burn by fire & $\begin{array}{l}\text { Reepithelialization and good granulation tissue } \\
\text { organization caused by Plantago major treatment in } \\
\text { an animal study. The epidermis exhibited well- } \\
\text { structured layers with no crusting }\end{array}$ & $2,7,58$ \\
\hline & Leaves & Plaster & $\begin{array}{l}\text { Carbuncle, Eczema, } \\
\text { Herpes, Urticaria }\end{array}$ & $\begin{array}{l}\text { The aqueous extract of Plantago major is endowed } \\
\text { with effective anti-inflammatory }\left(\mathrm{cAMP}^{4}, \mathrm{PDEI}^{5}\right) \\
\text { and anti-allergic effect }\end{array}$ & $\begin{array}{l}2,6,7 \\
41,51 \\
79\end{array}$ \\
\hline & Leaves & Plaster by salt & The bite of a rabid dog & Not found & $2,7,51$ \\
\hline & Leaves & Plaster & Chronic furuncle & According to commission $\mathrm{E}$ it was confirmed. & 7,80 \\
\hline \multirow[t]{2}{*}{ General } & $\begin{array}{l}\text { Leaves, seed, } \\
\text { Root }\end{array}$ & Oral extract & Fever & A strong disinfectant and antibacterial. & $2,7,81$ \\
\hline & Leaves & Plaster & Lymphedema & $\begin{array}{l}\text { Selenium is effective in treatment of Lymphedema. } \\
\text { Selenium is in Plantago spp. }\end{array}$ & $2,7,82$ \\
\hline
\end{tabular}

1: Gamma-aminobutyric acid (GABA), 2: Ears, nose and throat (ENT), 3: Minimum inhibitory concentration (MIC), 4: Cyclic adenosine monophosphate (cAMP), 5: Phosphodiesterase inhibitor (PDEI).

Prescription of different products of various parts of this plant indicated the accuracy of TPM scholars from centuries ago. For example, a roasted form of $P$. major seeds was used excessively in patients with gastrointestinal bleeding and ulcerative colitis in TPM $(13,15)$, and Balakhnina et al. have shown that roasted plantain reduces the amount of heavy metals in this plant (64). Another point in TPM resources was the combination of this plant with other plants (poly herbal compounds). For example, boiled plantains with lentils, salt and vinegar for the treatment of dysentery was prescribed $(2,13)$. The likely reason for using the poly herbal compound, is usually to modify the effects (synergist) or side effects of the primary and secondary metabolites of P. major. Because of the lack of modern laboratory tests in ancient times, TPM scholars could not find the effective ingredients of the plants. Plantago major is an important medicinal plant with different pharmacological properties including antiinflammation, analgesic, wound healing, antipyretic, antitussive, anti-infective, anti-hemorrhagic, laxative, astringent, hemostatic activity and diuretic $(60,65)$. A wide range of biological activities involve antimicrobial, antiasthmatic, anti-inflammatory, antitussive, and immunomodulating actions (20-22). In this review study, all applications of Plantain in TPM were collected from 1000 years ago and temperamental properties of this plant were described whereas Nazarizadeah et al. conducted a study based on traditional uses of Plantain in different countries 
in 2013 (60). In both of papers applications of Plantain in modern phytotherapy were listed. In our study, most of the properties of Plantain in TPM by recent studies in modern phytotherapy have been confirmed (Table1). Even its mechanism in the treatment of some diseases, such as its effect on GABA, estrogen agonist, inhibition of prostaglandins synthesis etc. have been found on seizure, menorrhagia and pain respectively $(44,66,67)$.

\section{Conclusions}

Based on TPM and modern medicine, this plant has many medical applications in the form of oral or topical, without serious side effects. Considering that some of the beneficial effects of plantain in TPM have not been proven in modern medicine, future clinical and experimental research is recommended for proving other therapeutic effects of Plantago major. Due to the availability of this plant in many countries and its therapeutic benefits, it is recommended that various drug products from this plant be made and be available to patients and to be used as a complementary medicine along with conventional treatments.

\section{Acknowledgments:}

This study was a part of a Ph.D. thesis supported by Mashhad University of Medical Sciences.

\section{Conflict of Interest:}

There is no conflict of interest to be declared.

\section{Authors' contributions:}

All authors contributed to this project and article equally. All authors read and approved the final manuscript.

\section{References:}

1) Wang H, Zhao C, Huang Y, Wang F, Li Y, Chung HY. Chemical Constituents and Bioactivities of Plantaginis Herba. Hong Kong Med J. 2015; 22: 29-35.

2) Aghili M. Makhzan-O-L Advieh. Tehran: Tehran University of Medical Science Press; 2008.

3) Mozaffarian V. Identification of medicinal and aromatic plants of Iran. Tehran: Farhang moaser; 2012.

4) Shahabi S, Hassan ZM, Mahdavi M, Dezfouli M, Torabi Rahvar M, Naseri M, et al. Hot and Cold natures and some parameters of neuroendocrine and immune systems in traditional Iranian medicine: a preliminary study. J Altern Complement Med. 2008; 14: 147-56. doi: 10.1089/acm.2007.0693.

5) Samuelsen AB. The traditional uses, chemical constituents and biological activities of Plantago major L. A review. J Ethnopharmacol. 2000; 71: 1-21. PMID: 10904143.

6) Al-Nafis I. Al-Shamil fi al-Tibb. Abu Dhabi: United Arab Emirates Pub; 2000.

7) Avicenna. The Canon of medicine. Beirut: Dar Maktab Al-Helal; 2009.

8) Aghili M. Qarabadin Kabir. Tehran: Tehran University of Medical Science Press; 1999.

9) Dioscorides's. Meteria Medica. Tehran: Tehran University of Medical Siences; 2005.

10) Osbaldeston T. Dioscorides Johannesburg: IBIDIS Press; 2000.

11) Biruni A. Al-saydanah Fi-elteb. Tehran: Asar publisher; 2004. Osbaldeston T. Dioscorides Johannesburg: IBIDIS PRESS; 2000.

12) Razi M. Al-havi (Arabic). Beirut: Lebanon: Dar Al -EHIA Al-Tourath Al-Arabi; 2002.

13) Arzani M. Tebb-E-Akbari Qom, Institute of Medical History, Islamic and Complementary Medicine, Iran University of Medical Sciences publisher; 2007.

14) Yavari M, Khodabandeh F, Tansaz M, Rouholamin S. A neuropsychiatric complication of oligomenorrhea according to iranian traditional medicine. Iran J Reprod Med. 2014; 12(7): 453-8. PMID: 25114666, PMCID: PMC4126248.

15) Jorjani S. Zakhireh Kharazmshahi [Treasure of Kharazmshahi]. Tehran, Iranian Culture Foundation (Original work published 1206 AD Tehran); 1976.

16) Nemereshina ON, Tinkov AA, Gritsenko VA, Nikonorov AA. Influence of Plantaginaceae species on E. coli K12 growth in vitro: Possible relation to phytochemical properties. Pharm Biol. 2015; 53: 715-24. doi: 10.3109/13880209.2014.940426. PMID: 25330854.

17) Mazzutti S, Ferreira S, Herrero M, Ibañez E. Intensified aqueous-based processes to obtain bioactive extracts from Plantago major and Plantago lanceolata. J Supercrit Fluids. 2017; 119: 64-71. doi: 10.1016/j.supflu.2016.09.008.

18) El-Gawad AMA, Mashaly IA, Ziada MEA, Deweeb MR. Phytotoxicity of three Plantago species on germination and seedling growth of hairy beggarticks (Bidens pilosa L.). J Basic Appl Sci. 2015; 2: 303-9. doi: 10.1016/j.ejbas.2015.07.003. 
19) Gonçalves S, Romano A. The medicinal potential of plants from the genus Plantago (Plantaginaceae). Ind Crops Prod. 2016; 83: 213-26. doi: 10.1016/j.indcrop.2015.12.038.

20) Akram M, Hamid A, Khalil A, Ghaffar A, Tayyaba N, Saeed A, et al. Review on medicinal uses, pharmacological, phytochemistry and immunomodulatory activity of plants. Int J Immunopathol Pharmacol. 2014; 27: 313-9. PMID: 25280022.

21) Fons F, Gargadennec A, Rapior S. Culture of Plantago species as bioactive components resources: a 20year review and recent applications. Acta Bot Gall. 2008; 155: 277-300. doi: 10.1080/12538078.2008.10516109.

22) Kuhn MA, Winston D. Herbal therapy and supplements: a scientific and traditional approach. Lippincott Williams \& Wilkins; 2000.

23) Jamilah J, Sharifa A, Sharifah N. GC-MS analysis of various extracts from leaf of Plantago major used as traditional medicine. World Appl Sci J. 2012; 17: 67-70.

24) Gomez - Flores R, Calderon C, Scheibel L, Tamez-Guerra P, Rodriguez-Padilla C, Tamez-Guerra R, et al. Immunoenhancing properties of Plantago major leaf extract. Phytother Res. 2000; 14: 617-22. PMID: 11113999.

25) Chiang LC, Chiang W, Chang MY, Lin CC. In vitro cytotoxic, antiviral and immunomodulatory effects of Plantago major and Plantago asiatica. Am J Chin Med. 2003; 31: 225-34. PMID: 12856861.

26) Türel I, Özbek H, Erten R, Öner AC, Cengiz N, Yilmaz O. Hepatoprotective and anti-inflammatory activities of Plantago major L. Indian J Pharmacol. 2009; 41: 120-4. doi: 10.4103/0253-7613.55211. PMID: 20442819, PMCID: PMC2861812.

27) Atta AH, Nasr SM, Mouneir SM. Potential protective effect of some plant extracts against carbon tetrachloride-induced hepatotoxicity. Afr J Tradit Complement Altern Med. 2006; 3: 1-9. doi: 10.4314/ajtcam.v3i3.114.

28) Gómez-Estrada H, Díaz-Castillo F, Franco-Ospina L, Mercado-Camargo J, Guzmán-Ledezma J, Medina J, et al. Folk medicine in the northern coast of Colombia: an overview. J Ethnobiol Ethnomed. 2011; 7: 27. doi: 10.1186/1746-4269-7-27.

29) Hriscu A, Stănescu U, Ionescu A, Verbuţă A. A pharmacodynamic investigation of the effect of polyholozidic substances extracted from Plantago sp. on the digestive tract. Rev Med Chir Soc Med Nat Iasi. 1989; 94: 165-170. PMID: 2075322.

30) Lans C, Turner N, Khan T, Brauer G. Ethnoveterinary medicines used to treat endoparasites and stomach problems in pigs and pets in British Columbia, Canada. Vet Parasitol. 2007; 148: 325-340. doi: 10.1016/j.vetpar.2007.06.014.

31) Atta A, Nasr SM, Mouneir SM. Antiulcerogenic effect of some plants extracts. Nat Prod Rad. 2005; 4: 25863.

32) Lima GR, Montenegro CD, Almeida CL, Athayde-Filho PF, Barbosa-Filho JM, Batista LM. Database Survey of Anti-Inflammatory Plants in South America. Int J Mol Sci. 2011; 12: 2692-749. doi: 10.3390/ijms12042692. PMID: 21731467, PMCID: PMC3127143.

33) Atta AH, Mouneir SM. Evaluation of some medicinal plant extracts for antidiarrhoeal activity. Phytother Res. 2005; 19: 481-5. doi: 10.1002/ptr.1639.

34) Ikawati Z, Wahyuono S, Maeyama K. Screening of several Indonesian medicinal plants for their inhibitory effect on histamine release from RBL-2H3 cells. J Ethnopharmacol. 2001; 75: 249-56. doi: 10.1016/S03788741(01)00201-X. PMID: 11297859.

35) Hetland G, Samuelsen A, Loslash V, Paulsen B, Aaberge I, Groeng E, et al. Protective effect of Plantago major L. pectin polysaccharide against systemic Streptococcus pneumoniae infection in mice. Scand J Immunol. 2000; 52: 348-55. doi: 10.1046/j.1365-3083.2000.00793.x. PMID: 11013005.

36) Matev M, Angelova I, Koĭchev A, Leseva M, Stefanov G. Clinical trial of a Plantago major preparation in the treatment of chronic bronchitis. Vutr Boles. 1981; 21: 133-7. PMID: 7101883.

37) Doan DD, Nguyen N, Doan H, Nguyen T, Phan T, Van Dau N, et al. Studies on the individual and combined diuretic effects of four Vietnamese traditional herbal remedies (Zea mays, Imperata cylindrica, Plantago major and Orthosiphon stamineus). J Ethnopharmacol. 1992; 36: 225-31. doi: 10.1016/03788741(92)90048-V. PMID: 1434681.

38) Nhiem NX, Tai BH, Van Kiem P, Van Minh C, Cuong NX, Tung NH, et al. Inhibitory activity of Plantago major L. on angiotensin I-converting enzyme. Arch Pharm Res. 2011; 34: 419-23. PMID: 21547673.

39) Aziz SA, See TL, Khuay LY, Osman K, Bakar MAA. In vitro effects of plantago major extract on urolithiasis. Malays J Med Sci. 2005; 12: 22-6. PMID: 22605954. 
40) Yazdian MA, Gheisari M, Khodadoost M, Barikbin B, Yazdian M, Askarfarashah M, et al. Evaluation of Plantago major aqueous extract in treatment of acute urticaria. Int J Biosci. 2014; 5: 182-8.

41) Yazdian MA, Khodadoost M, Gheisari M, Kamalinejad M, Ehsani AH, Barikbin B. A Hypothesis on the Possible Potential of Plantago Major in the Treatment of Urticaria. Hong Kong Med J. 2014; 3: $123-6$.

42) Angarskaya M, Sokolova V. The effect of plantain (Plantago major) on the course of experimental atherosclerosis in rabbits. Bull Exp Biol Med. 1963; 53: 410-2. doi: 10.1007/BF00783859.

43) Alarcon-Aguilar F, Vega-Avila E, Almanza-Perez J, Velasco-Lezama R, Vazquez-Carrillo L, RomanRamos R. Hypoglycemic effect of Plantago major seeds in healthy and alloxan-diabetic mice. Proc West Pharmacol Soc. 1998; 2006: 51.

44) Matsuura N, Aradate T, Kurosaka C, Ubukata M, Kittaka S, Nakaminami Y, et al. Potent protein glycation inhibition of plantagoside in Plantago major seeds. Biomed Res Int. 2014; 2014: 208539. doi: $10.1155 / 2014 / 208539$.

45) Atta A, El-Sooud KA. The antinociceptive effect of some Egyptian medicinal plant extracts. J Ethnopharmacol. 2004; 95: 235-8. doi: 10.1016/j.jep.2004.07.006.

46) Mazzutti S, Riehl CA, Ibañez E, Ferreira SR. Green-based methods to obtain bioactive extracts from Plantago major and Plantago lanceolata. J Supercrit Fluids. 2017; 119: 211-20. doi: 10.1016/j.supflu.2016.09.018.

47) Mello JC, Gonzalez MV, Moraes VW, Prieto T, Nascimento OR, Rodrigues T. Protective Effect of Plantago major Extract against t-BOOH-Induced Mitochondrial Oxidative Damage and Cytotoxicity. Molecules. 2015; 20: 17747-59. doi: 10.3390/molecules201017747.

48) Mello JC, Guimaraes NS, Gonzalez MV, Paiva JS, Prieto T, Nascimento OR, et al. Hydroxyl scavenging activity accounts for differential antioxidant protection of Plantago major against oxidative toxicity in isolated rat liver mitochondria. J Pharm Pharmacol. 2012; 64: 1177-87. doi: 10.1111/j.20427158.2012.01496.x.

49) Karima S, Farida S, Mihoub ZM. Antioxidant and antimicrobial activities of Plantago major. Int j pharm sci. 2015; 7: 58-64.

50) Stenholm A, Goransson U, Bohlin L. Bioassay-guided supercritical fluid extraction of cyclooxygenase-2 inhibiting substances in Plantago major L. Phytochem Anal. 2013; 24: 176-83. doi: 10.1002/pca.2398.

51) Chiang L, Chiang W, Chang M, Ng L, Lin C. Antiviral activity of Plantago major extracts and related compounds in vitro. Antiviral Res. 2002; 55: 53-62. doi: 10.1016/S0166-3542(02)00007-4. PMID: 12076751.

52) Metiner K, Ozkan O, Ak S. Antibacterial effects of ethanol and acetone extract of Plantago major L. on Gram positive and Gram negative bacteria. Kafkas Univ Vet Fak Derg. 2012; 18: 503-5. doi: 10.9775/kvfd.2011.5824.

53) Ponce-Macotela M, Navarro-Alegria I, Martinez-Gordillo M, Alvarez-Chacon R. In vitro effect against Giardia of 14 plant extracts. Rev Invest Clin. 1993; 46: 343-7. PMID: 7839013.

54) Sharma H, Yunus G, Agrawal R, Kalra M, Verma S, Bhattar S. Antifungal efficacy of three medicinal plants Glycyrrhiza glabra, Ficus religiosa, and Plantago major against oral Candida albicans: A comparative analysis. Indian J Dent Res. 2016; 27: 433-6. doi: 10.4103/0970-9290.191895.

55) Galvez M, Martí C, Lopez-Lazaro M, Cortes F, Ayuso J. Cytotoxic effect of Plantago spp. on cancer cell lines. J Ethnopharmacol. 2003; 88: 125-30. doi: 10.1016/S0378-8741(03)00192-2. PMID: 12963131.

56) Oto G, Ekin S, Ozdemir H, Levent A, Berber I. The effect of Plantago Major Linnaeus on serum total sialic acid, lipid-acibound sialic d, some trace elements and minerals after administration of 7, 12-Dimethylbenz (a) anthracene in rats. Toxicol Ind Health. 2011; 28: 334-42. doi: 10.1177/0748233711412422.

57) Velasco-Lezama R, Tapia-Aguilar R, Román-Ramos R, Vega-Avila E, Pérez-Gutiérrez MS. Effect of Plantagomajor on cell proliferation in vitro. J Ethnopharmacol. 2006; 103: 36-42. doi: 10.1016/j.jep.2005.05.050. PMID: 16226858.

58) Amini M, Kherad M, Mehrabani D, Azarpira N, Panjehshahin M, Tanideh N. Effect of Plantago major on burn wound healing in rat. J Appl Anim Res. 2010; 37: 53-6. doi: 10.1080/09712119.2010.9707093.

59) Zubair M, Ekholm A, Nybom H, Renvert S, Widen C, Rumpunen K. Effects of Plantago major L. leaf extracts on oral epithelial cells in a scratch assay. J Ethnopharmacol. 2012; 141: 825-30. doi: 10.1016/j.jep.2012.03.016. PMID: 22465512.

60) Nazarizadeh A, Mikaili P, Moloudizargari M, Aghajanshakeri S, Javaherypour S. Therapeutic uses and pharmacological properties of Plantago major L. and its active constituents. J Basic Appl Sci Res. 2013; 3: 212-21. 
61) Guil J, Rodríguez-Garcí I, Torija E. Nutritional and toxic factors in selected wild edible plants. Plant Foods Hum Nutr. 1997; 51: 99-107. doi: 10.1023/A:1007988815888. PMID: 9527345.

62) Parra AL, Yhebra RS, Sardiñas IG, Buela LI. Comparative study of the assay of Artemia salina L. and the estimate of the medium lethal dose (LD50 value) in mice, to determine oral acute toxicity of plant extracts. Phytomedicine. 2001; 8: 395-400. doi: 10.1078/0944-7113-00044. PMID: 11695884.

63) Zubair M, Nybom H, Ahnlund M, Rumpunen K. Detection of genetic and phytochemical differences between and within populations of Plantago major L.(plantain). Sci Hortic. 2012; 136: 9-16. https://doi.org/10.1016/j.scienta.2012.01.002.

64) Balakhnina TI, Borkowska A, Nosalewicz M, Nosalewicz A, Włodarczyk TM, Kosobryukhov AA, et al. Effect of temperature on oxidative stress induced by lead in the leaves of Plantago major L. Int Agrophys. 2016; 30: 285-92. doi: 10.1515/intag-2015-0094.

65) Doan DD, Nguyen NH, Doan HK, Nguyen TL, Phan TS, Van Dau N, et al. Studies on the individual and combined diuretic effects of four Vietnamese traditional herbal remedies (Zea mays, Imperata cylindrica, Plantago major and Orthosiphon stamineus). J Ethnopharmacol. 1992; 36: 225-31. PMID: 1434681.

66) Doyle BJ, Frasor J, Bellows LE, Locklear TD, Perez A, Gomez-Laurito J, et al. Estrogenic effects of herbal medicines from Costa Rica used for the management of menopausal symptoms. Menopause. 2009; 16: 74855. PMID: 19424091.

67) Kavyanifard S, Heidarieh N, Jamalo F, Alinejad G, Alinejad M, Mohammad EA. Effect of hydro alcoholic extract of Plantago major L. on pentilentetrazol-induced seizures in male mice. J Gorgan Uni Med Sci. 2016; 18: 41-5.

68) Shipochliev T. Uterotonic action of extracts from a group of medicinal plants. Vet Med Nauki. 1980; 18: 94-8. PMID: 7314446.

69) Stewart A. Plantain (Plantago lanceolata)-a potential pasture species. Proceedings of the Conference-New Zealand Grassland Association. 1996; 77-86.

70) Tiwari A, Soni V, Londhe V, Bhandarkar A, Bandawane D, Nipate S. An overview on potent indigenous herbs for urinary tract infirmity: urolithiasis. Asian J Pharm Clin Res. 2012; 5: 7-12.

71) Hamedi S, Shams-Ardakani MR, Sadeghpour O, Amin G, Hajighasemali D, Orafai H. Designing mucoadhesive discs containing stem bark extract of Ziziphus jujuba based on Iranian traditional documents. Iran J Basic Med Sci. 2016; 19: 330-6. PMID: 27114804, PMCID: PMC4834124.

72) Hamedi S, Sadeghpour O, Shamsardekani MR, Amin G, Hajighasemali D, Feyzabadi Z. The Most Common Herbs to Cure the Most Common Oral Disease: Stomatitis Recurrent Aphthous Ulcer (RAU). Iran Red Crescent Med J. 2016; 18: e21694. doi: 10.5812/ircmj.21694. PMID: 27186385, PMCID: PMC4867162.

73) Gautam R, Saklani A, Jachak SM. Indian medicinal plants as a source of antimycobacterial agents. J Ethnopharmacol. 2007; 110: 200-34. PMID: 17276637.

74) Afsharypour S, Shafii K, Akbary ME, Zargarzadeh MR. Preparation and clinical evaluation of some antianorectal disease drugs obtained from medicineal. Med J Islam Repub Iran. 1996; 10: 73-7.

75) Awaad AS, El-Meligy RM, Soliman GA. Natural products in treatment of ulcerative colitis and peptic ulcer. Saudi J Gastroenterol. 2013; 17: 101-24. doi: 10.1016/j.jscs.2012.03.002.

76) Ozaslan M, Karagoz ID, Kiliç IH, Cengiz B, Kalender ME, Güldür ME, et al. Effect of Plantago major sap on Ehrlich ascites tumours in mice. Afr J Biotechnol. 2009; 8: 955-59. doi: 10.5897/AJB09.033.

77) Ibn Beytar Z. Al-Jamee Le-Mofradaat al- Adwiah wal- Aghziyah (Comprehensive Book in Simple Drugs and Foods). Beirut: Dar- Al-Kotob Al-ilmiyah; 2001.

78) Thomé RG, Santos HB, Santos FV, Oliveira RJ, De Camargos LF, Pereira MN, et al. Evaluation of healing wound and genotoxicity potentials from extracts hydroalcoholic of Plantago major and Siparuna guianensis. Exp Biol Med (Maywood). 2012; 237: 1379-86. doi: 10.1258/ebm.2012.012139. PMID: 23354396.

79) Rahimi R, Shams-Ardekani MR, Abdollahi M. A review of the efficacy of traditional Iranian medicine for inflammatory bowel disease. World J Gastroenterol. 2010; 16: 4504-14. doi: 10.3748/wjg.v16.i36.4504. PMID: 20857519, PMCID: PMC2945480.

80) Rotblatt M. Herbal medicine: expanded commission E monographs. Ann Intern Med. 2000; 133: 487. doi: 10.7326/0003-4819-133-6-200009190-00031.

81) Haddadian K, Haddadian K, Zahmatkash M. A review of Plantago plant. Indian J Traditional Knowedlege. 2014; 13: 681-5.

82) Antal DS, Canciu CM, Dehelean CA, Anke M. How much selenium do medicinal plants contain? Results of a research on wild-growing species from Western Romania. An Univ Oradea Fasc Biol. 2010; 17: 23-8. 